\title{
As implicações jurídicas no Brasil do tráfico de órgãos humanos
}

The legal implications of human organs trafficking in Brazil

\author{
Jaíza Sâmmara de Araújo Alves ${ }^{1}$ (iD) e Candice Renata Santana dos Santos ${ }^{2}$ (iD) \\ ${ }^{1}$ Faculdade de Petrolina (FACAPE) e Universidade do Estado da Bahia (UNEB), doutoranda em Direito Penal (Universidad de \\ Buenos Aires), emaill: jaiza.samara@facape.br \\ ${ }^{2}$ Faculdade de Petrolina (FACAPE), bacharel em Direito, emaill: renatacandice7@ hotmail.com
}

\section{RESUMO}

Atualmente há uma necessidade em se falar sobre o tráfico de órgãos pelo fato de ser uma situação que vem sido ampliada cada vez mais no território brasileiro e por todo o mundo. Quanto mais o tempo passa, mais pessoas precisam de algum tipo de transplante, pois assim como há um crescimento populacional, há também uma evolução na gravidade das doenças e o surgimento de outras. Além de que a quantidade de pessoas que emitem de forma pública o desejo de ser um doador durante a vida ou após a morte e a quantidade de famílias que permitem que haja a retirada de órgãos após a morte de algum dos seus familiares não consegue suprir a quantidade de pessoas que está à espera. Dessa forma muitos órgãos que poderiam ser utilizados para salvar vidas e consequentemente diminuir a fila do Sistema Único de Saúde (SUS), são literalmente enterrados. Ademais, a lei que versa sobre a doação de órgãos no Brasil é datada de 1997 e mesmo após 23 anos da criação desta, o assunto é pouco discutido. Existe inclusive uma necessidade de estudos mais aprofundados sobre o assunto em questão, pois é perceptível que mesmo existindo lei específica e princípios expressos na Constituição Federal Brasileira que acabam sendo feridos, pouquíssima importância tem sido dada à temática. A verdade é que quanto mais o tempo passa, mais a dimensão do problema tem se agravado.

Palavras-chave: Tráfico de órgão. Lei nº 9.434/97. Transplante. Doador.

\begin{abstract}
Currently there is a need to talk about organ trafficking because it is a situation that has been increasingly expanded in the Brazilian territory and around the world. The more time goes by, the more people need some kind of transplant, because just as there is a population growth, there is also an increase in diseases and the emergence of others. In addition, the number of people who publicly wish to be a donor during life or after death, and the number of families who allow organs to be removed after the death of one of their family members cannot meet amount of people waiting. Thus many organs that could be used to save lives and consequently shorten the line of the single health care system are literally buried. The law on organ donation in Brazil is dated 1997 and even after 22 years of its creation, the subject is little discussed. There is even a need for further studies on the subject, as it is noticeable that even though there are specific laws and principles expressed in the Brazilian Federal Constitution that end up being injured, very little importance has been given. The truth is, the more time goes by, the more the problem has gotten worse.
\end{abstract}

Keywords: Organ trafficking. Law no. 9.434/97. Transplant. Donor. 


\section{INTRODUÇÃO}

Apesar de a sociedade estar norteada por um conjunto de complexidades e a cada dia surgirem ainda mais necessidades aos seres humanos, é notório que há também um crescimento tanto no ramo da tecnologia quanto da ciência, fazendo com que diversas técnicas sejam descobertas. Mas é evidente que mesmo com avanços nessas áreas mencionadas, quanto mais o tempo passa, mais exigente a sociedade se torna. E o que antes era considerado apenas como possibilidade, vem se aperfeiçoando com o tempo e estudo.

Desde que as pessoas começaram a formar grupos entre si, há uma busca intensa pelo conhecimento. Em todas as áreas, as pessoas têm a necessidade de melhoria, não sendo diferente na área da saúde. E como na maioria das vezes, foram dados passos curtos e detalhados para que aos poucos fosse descoberta a possibilidade de "transferência" do órgão de uma pessoa para outra: situação tal que cerca de 200 anos atrás era impossível de ser considerada como alternativa para salvar e prolongar a perspectiva de vida.

Atualmente o transplante de órgãos está cada vez mais seguro por conta das evoluções da ciência e, consequentemente, os riscos nos procedimentos tendem a diminuir. Inclusive, tem sido uma alternativa para algumas mazelas existentes no momento, fazendo com que diversas pessoas tenham esperança e chances de mais anos de vida, ou seja, fazendo com que haja uma perspectiva de vida maior, para aqueles que conseguem a doação.

E mesmo com fronteiras sendo quebradas por meio de conquistas biológicas, uma delas continuava rodando o centro do assunto: o preconceito. Assim, o assunto era tido por muitos como absurdo e isso acabava dificultando a possibilidade de os médicos fazerem tal trabalho, de maneira que assunto acabava adentrando inclusive o cenário religioso.

Em relação à base histórica sobre quando foi efetivado o primeiro transplante no país existem duas datas. A primeira, com base em um artigo do JornalBrasileiro de Transplantes da Associação Brasileira de Transplantes de Órgãos, em que o primeiro histórico sobre um transplante no país é datado de 1964, realizado no Hospital de Servidores do Estado no Rio de Janeiro, onde o receptor teve o privilégio de receber um rim novo. Já com base no Jornal da Universidade de São Paulo, o primeiro transplante foi o de rins, mas datado em 1968 e aconteceu na Faculdade de Medicina de Ribeirão Preto da USP. Inclusive um dos médicos que participou de tal façanha para a época, conta que todos os envolvidos durante 3 anos, em todas as semanas, testavam em animais como fazer o transplante, para que se sentissem preparados. Apesar de existir

Ciências Sociais Aplicadas em Revista, v. 20, n. 38, p. 261-277, semestral, janeiro-junho, 2020. 
uma certa divergência quanto a data exata, é possível afirmar que a década de 60 trouxe umas das maiores evoluções no que diz respeito ao corpo humano. Já em relação ao transplante de outros órgãos, sabe-se que só houve tentativas bem-sucedidas na década de 80 (USP, Jornal. 2018).

Contudo, dentro deste contexto, existe uma grande problematização, que é o tráfico de órgãos humanos. No cenário atual, o Brasil é considerado o $2^{\circ}$ país do mundo que mais transplanta órgãos. Mas infelizmente mesmo estando em tal colocação, a demanda de doadores não é proporcional a quantidade de pessoas que ficam na lista de espera no Sistema Único de Saúde (SUS). E é por conta dessa desproporção que as pessoas que estão nesta fila, aguardando serem chamadas, acabam buscando refúgio em qualquer alternativa possível, ampliando dessa forma o mercado de tráfico de órgãos.

Ou seja, o tempo que se espera na fila para o transplante é consideravelmente grande, ao menos para quem está nas filas de espera, dado o fato de que as pessoas precisam geralmente de tal procedimento de forma urgente, o que acaba levando a muitas mortes durante esse processo de espera.

Deste modo, de um lado estão pessoas dispostas a sobreviver de qualquer forma através do recebimento ilícito, diga-se de passagem, do órgão que precisam, e de outro lado, pessoas em situação de vulnerabilidade, aceitando o que for preciso para mudar o cenário em que vivem e melhorar à vida e o contexto de sua família.

E apesar de tal crime afrontar de forma direta a Constituição Federal e leis específicas, é um dos crimes mais rentáveis no Brasil e no mundo, posto que o crime em questão é praticado por organizações criminosas que se utilizam de meios de comunicações, da facilidade trazida pelo estímulo do lucro de forma "fácil" e a conexão entre grupos de diversos países, tornando ainda mais difícil a atuação preventiva e repressiva dos entes responsáveis pela inibição de tal ato.

\section{TRANSPLANTE DE ÓRGÃOS}

\subsection{HISTÓRICO DE TRANSPLANTE DE ÓRGÃOS}

Antes do século 16 o corpo humano era tido com algo sagrado e até intocável, e por esse motivo, nunca havia sido investigado com o objetivo de estudo. Então com o fim do século 16 e o início do século 17 alguns anatomistas, que para época eram considerados curiosos, começaram a examinar o corpo humano fazendo com que aos poucos a visão de que o mesmo era apenas uma

Ciências Sociais Aplicadas em Revista, v. 20, n. 38, p. 261-277, semestral, janeiro-junho, 2020. 
máquina, fosse modificada. O anseio por "estudar" de forma detalhada um ser tão complexo se deu pelo fato de que ao longo do tempo a ciência não conseguia mais dar contade responder todas as questões que a sociedade trazia, afinal quanto mais o tempo vai passando, mais perguntas surgem, fazendo com que o ser humano se torne cada dia mais enigmático (JUNGES, 1999, p. 207.).

Dentro do contexto de tantas mudanças, pode-se dizer que o marco para que surgisse o transplante de órgãos foi a possibilidade do estudo mencionada acima. Mas para que o transplante se efetive existe a necessidade de doação, ou seja, uma pessoa através de ato voluntário e sem nenhum objetivo de lucro precisa querer retirar uma parte de si para que outra pessoa seja beneficiada. E dentre as possibilidades estão: a modalidade inter vivos e a post mortem, onde a primeira é a própria pessoa que decide por livre e espontânea vontade, enquanto a segunda são os familiares que escolhem fazer o transplante (BUONICORE, 2014. p.7.).

É verdade que atualmente existem diversas técnicas seguras, mas faz-se necessário relatar o início de tal feito. A primeira tentativa bem-sucedida em humanos conhecida e relatada pelos livros foi feita por um cirurgião em 1869, onde o mesmo transplantou uma parte da pele de uma pessoa nela mesma, conhecido como autotransplante. Há relatos também de que em 1900, um outro cirurgião criou uma técnica de sutura vascular, dando início ao transplante de rins, tireoide e até de corações em animais. Mas o grande problema é que, após dias, os transplantados morriam. Foi apenas a partir de 1950 que se efetivaram os primeiros transplantes de órgãos não regeneráveis, como por exemplo, o coração (GARCIA, et al , 2006. p.3).

Historicamente existiram alguns fatores que fortaleceram o transplante de órgãos. Dentre eles está a descoberta da morte cerebral e a utilização da ciclosporina, um medicamento que evitava uma possível rejeição do organismo (FERNÁNDEZ, 2000. p.282).

Portanto, após tantas décadas é possível perceber que a medicina tem avançado bastante, fazendo com que haja ainda mais esperança para aqueles que não possuem uma alternativa para a sobrevivência, senão a de transplante de algum órgão.

\subsection{DEFINIÇÃO DE TRANSPLANTE E AS MODALIDADES EXISTENTES}

É interessante e plausível trazer não só o conceito do que é um transplante, mas diferenciar este de implante e enxerto, fazendo com que posteriormente não haja confusões quanto aos termos. De acordo com Rita de Cássia Curvo Leite (2000, p. 111) "transplante significa o ato ou efeito de 
transplantar, mudar de um lugar para outro". Já enxertar "é o mesmo que inserir alguma coisa em outro lugar de modo a se tornar parte integrante deste último" (Curvo Leite, 2000, p. 111). Por fim, implantar consiste em inserir. O objetivo dessa diferenciação se dá pelo fato de que muitas vezes, os conceitos trazidos são utilizados de formas diferentes em locais diversos, fazendo com que muitos autores não façam distinção entres os dois. De forma mais integral sobre o trasnsplante Carlos Maria Romeo Casabona (1979, p. 200) aduz que:

Trata-se de uma técnica cirúrgica, denominada cirurgia substitutiva, que se caracteriza em essência porque introduz no corpo do paciente um órgão ou tecido pertencente a outro ser humano, vivo ou falecido, com o fim de substituir outros da mesma entidade pertencente ao receptor, porém, que tenha perdido total ou sensivelmente sua função. A natureza deste tipo de intervenção, do ponto de vista do receptor, posto que em relação ao doador a situação é diversa, é de estima-la, em consequência, com uma intervenção curativa, sempre que exista a indicação terapêutica e se aplique a técnica adequada ao caso.

Além de trazer a definição acima mencionada, é válido mencionar a definição do que são órgãos. E de acordo com o dicionário médico Stedman (2003, p. 457), órgãos seriam "qualquer parte do corpo que exerce função específica, como de respiração, secreção, digestão etc.”. É interessante lembrar que não existe apenas o transplante de órgãos, há também o de tecidos.

Dentre as modalidades existentes, Lima (1996, p. 26) traz três classificações. A primeira explica o autotransplante como sendo "a transferência de tecido ou órgão, de um lugar para outro, na mesma pessoa". O isotransplante que é o "transplante de tecido ou órgão entre indivíduos do mesmo gênero e com caracteres hereditários idênticos". Por último, o homotransplante que é o "transplante de tecido ou órgão entre indivíduos do mesmo gênero com diferentes caracteres hereditários".

\subsection{A LEI QUE REGULA O TRANSPLANTE DE ÓRGÃOS NO BRASIL}

Existe atualmente uma lei que regula este assunto, e antes de adentrar no estudo de tal lei, é essencial que se faça uma breve análise do histórico legal do transplante de órgãos, pois dessa forma será possível compreender tais avanços legislativos, posto que, assim como as demais leis existentes em nosso ordenamento jurídico, ao longo do tempo, as normas vão se aprimorando.

Inicialmente entrou em vigor a Lei $\mathrm{n}^{\circ} 4.280$ de 1963, que apenas trazia a modalidade post mortem. De acordo com esta modalidade, era possível a extirpação de pessoa falecida com fins de 
transplante de córnea. Além disso, tal lei trazia em seu artigo primeiro três possibilidades de manifestação de vontade para que houvesse a doação, sendo elas: a não oposição do cônjuge ou parentes até segundo grau, a manifestação escrita e positiva do titular em vida e o consentimento das corporações religiosas ou civis das quais o de cujus fazia parte e seriam responsáveis pelo destino dos despojos (BRASIL, 1963).

Após 5 anos, entrou em vigor a Lei $n^{\circ} 5.479$ de 1968, que fez com que a lei anterior fosse revogada. Trazendo consigo a opção da doação inter vivos, bem como mudanças quanto a autorização no caso da retirada de órgãos que deveria ser expressa, fosse por parte da pessoa que faleceu, pelos parentes ou responsáveis, sempre por escrito (BRASIL, 1968). Apesar de tais regras, a lei em questão nunca foi regulamentada pelo Poder Executivo. E para segurança de todos, a Constituição Federal de 1988 trouxe em seu artigo 199, mais especificamente no parágrafo $4^{\circ}$, a vedação da comercialização de quaisquer que fossem os órgãos.

Algum tempo depois, a Lei $n^{\circ} 8.489 / 92$ acabou revogando a Lei ${ }^{\circ}$ 5.479/68. Naquela, o artigo terceiro trazia duas condições para a disposição gratuita de uma ou de várias partes do corpo post mortem para fins terapêuticos e científicos. No inciso I dizia que deveria ser: "por desejo expresso do disponente manifestado em vida, através de documento pessoal ou oficial"; O II falava que: "na ausência do documento referido no inciso I, a retirada de órgãos seria procedida, se não houvesse manifestação em contrário, por parte do cônjuge, ascendente ou descendente" (BRASIL, 1992). Desta forma entende-se que se não houvesse a manifestação expressa em vida como previa o inciso I, o inciso II autorizava a retirada do órgão desde que não houvesse a manifestação contrária do cônjuge, ascendente ou descendente, sendo, portanto, um consentimento presumido.

Posteriormente, entrou em vigor a Lei no 9.434/97, sendo esta regulamentada pelo decreto $n^{\circ} 2.268 / 97$, provocando a revogação tanto da Lei $n^{\circ} 8.489 / 92$, bem como do decreto $n^{\circ} 879$. Vale ressaltar que a Lei ${ }^{\circ}$ 9.434/97 ainda continua em vigor, porém somente foi alterada por três vezes desde que começou a viger, através das modificações trazidas pelas leis $n^{\circ} 10.211 / 2001, n^{\circ}$ 11.521/2007 e n 11.633/2007, de modo que, de 2007 para cá, a sociedade já passou por transformações, de modo que a não modernização da lei, pode trazer prejuízos às situações atuais que possam surgir, mas que não estejam contempladas na legislação de 1997.

Contudo, quanto ao consentimento, ocorreu um grande avanço na legislação, o que reverbera na prática, posto que fora retirada da Lei $\mathrm{n}^{\circ} 9.434$ a chamada doação presumida, que existia no artigo $4^{\circ}$ anterior à vigência da Lei $n^{\circ} 10.211 / 01$. Sendo assim desde 2001, a retirada de tecidos, órgãos ou partes do corpo no caso de pessoa falecida dependerá sempre de autorização

Ciências Sociais Aplicadas em Revista, v. 20, n. 38, p. 261-277, semestral, janeiro-junho, 2020. 
por parte do cônjuge ou parente, maior de idade, obedecida a linha sucessória, reta ou colateral, até o segundo grau, firmada em documento subscrito por duas testemunhas presentes à verificação da morte.

É importante trazer a diferenciação entre as modalidades inter vivos e post mortem. A primeira nada mais é do que uma modalidade de transplante entre pessoas vivas e de acordo com Curvo Leite (2000, p. 119) ocorre quando "a parte anatômica provém de pessoa viva através de uma operação cirúrgico-terapêutica ordinária e proveniente de um incidente ou fato lesivo". Já o post mortem, segundo a mesma autora, ocorre "quando procede de um corpo humano sem vida" (CURVO LEITE, 2000, p. 119).

Ressalte-se que, na hipótese da modalidade inter vivos, o primeiro requisito para a realização de transplantes requerido pela Lei $n^{\circ} 9.434 / 97$, em seu artigo $9^{\circ}$, é que ocorra de forma gratuita e sempre por pessoa juridicamente capaz, novamente vedando qualquer tipo de comercialização (BRASIL, 1997).

É importante ressaltar que apesar de existir a possibilidade de doação de órgãos, essa só poderá ser feita nos casos de doador com vida, se forem órgãos duplos, e caso a retirada não impeça ou prejudique a vida dele. Sendo assim o código mais uma vez se preocupou com as pessoas envolvidas e dessa forma as protegeu de danos maiores por conta de tal procedimento. Entre os órgãos passíveis de doação entre vivos está o rim, a medula óssea, parte do fígado, parte do pulmão e parte do pâncreas.

No que diz respeito à modalidade post mortem, a grande questão que envolve oassunto é o momento da morte do doador. Sendo este um dos critérios trazidos pela Resolução no ${ }^{\circ}$ 1480/97 do Conselho Federal de Medicina, ou seja, o diagnóstico comprovando a morte encefálica. Tal comprovação é inclusive requisito essencial constante na Lei ${ }^{\circ}$ 9.434/97, devendo haver a autorização do cônjuge ou parente, acrescido de um documento assinado por duas testemunhas presentes à verificação da morte.

Ressalta-se que mesmo existindo uma Lei sobre o assunto em questão, há também a Portaria de nº 201 de 2012 que traz não só a possibilidade, como também as regras de transplante no Brasil no caso de estrangeiros não residentes no país. Por fim, há também ha a Resolução RDC $n^{\circ}$ 66/2009, que trata sobre o transporte de órgãos humanos em hipotermia no Brasil, normatizando assim tudo que está relacionado com o deslocamento dos referidos órgãos, trazendo assim segurança em todas as etapas (BRASIL, 2009).

Ciências Sociais Aplicadas em Revista, v. 20, n. 38, p. 261-277, semestral, janeiro-junho, 2020. 
Deste modo é possível perceber que existem normas jurídicas no Brasil suficientes para resguardar todos os momentos possíveis quanto ao transplante, seja ele entre pessoas vivas ou em caso de morte do doador, mas que diante da realidade trazida pelo tráfico de drogas, não possui tanta eficácia.

\section{O TRÁFICO DE ÓRGÃ̃S}

Sabe-se que, ao longo da história, os seres humanos estão em constante avanço. E junto com tal desenvolvimento, surgem novas questões a serem resolvidas, trazendo assim, a necessidade de leis. Diante do problema do tráfico de órgãos, torna-se imprescindível a utilização tanto do Direito Penal quanto da Constituição Federal. E por mais que pouco se fale sobre oassunto, infelizmente o tráfico de órgãos ou comércio ilegal de órgãos humanos é real tanto dentro do cenário brasileiro quanto internacionalmente.

Com base em pesquisas feitas pela Organs Watch, uma organização sediada na Universidade da Califórnia, Estados Unidos, esse comércio ilegal pode ser encontrado antes mesmo dos anos 90, der maneira que, enquanto as pessoas que "doavam" esses órgãos faziam parte de uma classe baixa ou menosprezada, os médicos envolvidos tinham grande prestígio e poder na sociedade. Na maioria das vezes, era forjada uma morte cerebral só para produzir a cota necessária de órgãos de qualidade. O grande problema é que boa partedas vítimas eram ameaçadas a vender seus órgãos e acabavam ficando com medo de denunciar quem quer que fosse (SILVA, 2016).

No Brasil, a vedação do tráfico de órgão se encontra tipificada no artigo 15 da Lei $\mathrm{n}^{\circ}$ 9.434/97, que aduz o seguinte:

Art. 15. Comprar ou vender tecidos, órgãos ou partes do corpo humano: Pena- reclusão, de três a oito anos, e multa, de 200 a 360 dias-multa.

Parágrafo único. Incorre na mesma pena quem promove, intermedeia, facilita ou aufere qualquer vantagem com a transação (BRASIL, 1997).

Ressalte-se que, esta vedação consta não somente na lei específica, mas também na Constituição Federal, em seu artigo 199, parágrafo quarto:

Art.199. A assistência à saúde é livre à iniciativa privada. §4- A lei disporá sobre as condições e os requisitos que facilitem a remoção de órgãos, tecidos e substâncias humanas para fins de transplante, pesquisa e tratamento, bem como a coleta, processamento e transfusão de sangue e seus derivados, sendo vedado todo tipo de comercialização (BRASIL, 1988).

Ciências Sociais Aplicadas em Revista, v. 20, n. 38, p. 261-277, semestral, janeiro-junho, 2020. 
Infelizmente existem pessoas ao redor do mundo dispostas a se tornarem ricas a qualquer custo e acima de qualquer lei. Há inclusive estimativas da Polícia Federal de que esse mercado ilegal é o terceiro no ranking dos crimes mais lucrativos que existem, sendo superado pelo o tráfico de drogas e de armas (AMARAL, 2018).

Inclusive, diante de todos os transplantes renais que acontecem ao redor do mundo, cerca de 5\% a 10\% acontecem por meio dessa ilegalidade. E segundo a Organização Mundial de Saúde (OMS) os países mais procurados para prática dessa ilegalidade são: Paquistão, China, Filipinas e Índia (OMS, 2009). Nestes países existe um turismo de transplantação, onde pessoas muito ricas fazem questão de ir para conseguir o que tanto desejam, visto que do outro lado, existem pessoas desfavorecidas, que precisam de todas as formas modificar a sua realidade, estando dispostas a se submeter a qualquer situação, como por exemplo, permitir uma mutilação dos seus próprios corpos, a fim de obter algum lucro.

$\mathrm{Na}$ China, a facilidade com que se consegue órgãos chega a ser assustadora. Lá, inicialmente os prisioneiros condenados à morte tinham que dispor dos seus órgãos independentemente de consentirem ou não. Após práticas reiteradas de tal atrocidade mencionada anteriormente, ou seja, a disposição de órgãos de executados condenados à prisão sem eles terem se voluntariado, vários líderes políticos e grupos de direitos humanos rechaçaram esse tipo de conduta que até este momento eram aceitas pelo governo. $\mathrm{Na}$ atualidade, apesar de haver uma necessidade de o prisioneiro expressar sua vontade ao transplante, existe a possibilidade da obtenção desse consentimento meidnate fraude, por exemplo, afirmando-se aos doadores que seu órgãos serão doados para pessoas necessitadas de forma gratuira, o que na verdade é apenas uma fachada, para uma realidade obscura (EL PAÍS, 2014).

No Paquistão, apesar de existirem leis que proíbam o enriquecimento através do transplante de órgãos, a situação não difere muito da China, posto que naquele é possível conseguir um rim em poucos minutos, bastando que alguém tenha dinheiro para isso (O GLOBO, 2017).

À vista desses fatos, é evidente que a comercialização de órgãos não se trata somente de uma questão de pobreza e vulnerabilidade dos países onde tal prática é mais frequente. Contudo, é possível constatar um grande e forte fator social, por trás de tamanha atrocidade, tendo em vista que esse comércio ilegal beneficia principalmente às pessoas consideradas ricas e, consequentemente, às elites destes países onde o tráfico de órgãos ocorre de forma rotineira. E como na maioria das vezes é essa elite quem tem o poder de dominação no interior desses países, a prática por mais que

Ciências Sociais Aplicadas em Revista, v. 20, n. 38, p. 261-277, semestral, janeiro-junho, 2020. 
feita de forma bastante oculta, acontece da forma mais fria e calculista possível, afinal, além de ser possível comprar um órgão quando se possui bastante dinheiro, igualmente é possível comprar o silêncio das demais pessoas que estejam envolvidas na prática do tráfico ou comércio ilegal de órgãos humanos.

\section{A DEEP WEB}

Assim como as demais áreas de conhecimento, a tecnologia tem alcançado proporções cada vez maiores. O que ontem era novidade, hoje não passa de um conhecimento ultrapassado. E como qualquer outra coisa, tem o seu lado positivo e negativo. É certo que a internet modificou a vida dos seres humanos e proporcionou diversas melhorias. Mas há que se destacar aqui, uma utilização errônea da inteligência, vinculada à conexão mundial.

De acordo com o site de significados a deep web "é uma definição dada para uma zona da internet que não pode ser detectada de forma prática pelos tradicionais motores de busca, o que garante o anonimato e a privacidade para os seus navegantes" (SIGNIFICADOS, 2019). E apesar de inicialmente ter sido criada pela força militar dos Estados Unidos com o objetivo de formar anonimamente alguns sistemas de informações, hoje é composta por um conjunto de sites que costumam trazer assuntos de caráter ilegal e imoral, inclusive o tema do tráfico de órgãos.

Ressalte-se que nesta plataforma, existe a possibilidade de se adquirir órgãos sem que haja maiores problemas, havendo a estimativa de que, com relação ao comércio ilegal de órgãos humanos, haja a circulação entre 600 milhões e 1,2 bilhão de dólares a cada ano (PELLEGRINI, 2018).

\section{O TRÁFICO DE ÓRGÃOS NO BRASIL E SUAS IMPLICAÇÕES JURÍDICAS}

No Brasil, o cenário não é tão distante quando comparado aos outros países. O problema começa no fato de que a quantidade de receptores, no que diz respeito à doação de órgãos, é superior a quantidade de doadores. E o motivo da desproporção está na demora para que se consiga o órgão através do Sistema Único de Saúde (SUS), afinal esse é o único caminho possível diante da lei.

Ciências Sociais Aplicadas em Revista, v. 20, n. 38, p. 261-277, semestral, janeiro-junho, 2020. 
E mesmo o Brasil tendo um dos melhores históricos e estar praticamente no topo do ranking mundial ${ }^{1}$ quanto ao transplante de órgãos, e ao longo do tempo estar conseguindo melhorar suas taxas, há alguns impasses que acabam prejudicando os pacientes que necessitam de algum órgão para sobreviver.

É sabido que existe uma morosidade quanto à espera nas filas dos hospitais o que acaba ensejando a morte de muitos pacientes, pois existem transplantes que chegam a demorar mais de 2 anos para serem realizados. Outras dificuldades que acabam influenciando nesta lentidão é o fato de que existem órgãos mais fáceis de serem transplantados que outros, bem como o tamanho do órgão a ser doado e até a compatibilidade do doador com o receptor. E o que mais espanta e preocupa ao mesmo tempo, é o fato de que apenas cerca de $32 \%$ dos que estão à espera, conseguem sobreviver até a chegada de um órgão, sendo este o maior problema encontrado, dando base para que as pessoas necessitadas acabem procurando alternativas diferentes. E uma das alternativas é o tráfico de órgãos (Associação Brasileira de Transplante de Órgãos, 2019).

Assim, com um número tão alarmante, e baixo por sinal, de cidadãos que conseguem esperar pelo tempo de espera que é informado pelo Sistema Único de Saúde, as pessoas com condições financeiras melhores acabam se envolvendo em um comercio ilegal, visando o seu próprio bem- estar e deixando de lado as questões jurídicas e até as sanções penais impostas para quem comete esse tipo de crime.

Infelizmente não é somente o doador e o receptor que fazem parte do negócio. Ou seja, não é um simples polo ativo e um polo passivo. Há muitas outras pessoas envolvidas. Já foi comprovado que em alguns hospitais brasileiros existe uma falsificação da morte encefálica para que os médicos e os responsáveis dos hospitais possam se beneficiar de tal situação (PAVESI, 2013).

Assim, apesar de a Constituição Federal em seu art. $1^{\circ}$, inciso III e a própria Lei $\mathrm{n}^{\circ}$ 9.434/97 tutelarem a dignidade da pessoa humana, a proteção de direitos e garantias fundamentais, bem como a dignidade da pessoa humana ser o alicerce do principal princípio da $\mathrm{CF} / 88$, vedando qualquer tipo de comercialização de órgãos e tecidos ou corpos inteiros, tal proteção não constitui impedimento para que haja tal crime. É importante ressaltar que a doação de órgãos nada mais é do que uma exceção ao princípio da indisponibilidade.

\footnotetext{
${ }^{1}$ No ano de 2018, o Brasil ocupou o $2^{\circ}$ lugar no ranking mundial de transplante de órgãos, ficando apenas atrás dos Estados Unidos (RADIO EBC, 2018).
} 
Deste modo, mesmo que a pessoa tenha o objetivo de dispor da sua dignidade humana, agindo conforme, os seus próprios interesses, isso não poderá ser atendido pelo fato de entrar em conflito com o princípio acima mencionado, por ser ele indisponível, sendo este o argumento que envolve a vedação referente ao tráfico de órgãos.

Diante da Lei n ${ }^{\circ}$ 9.434/97, o bem jurídico defendido é, portanto, a dignidade humana, sendo ele o norteador de todos os outros princípios existentes. E pelo fato de não trazer em seus artigos nenhuma qualidade especial, o sujeito ativo neste delito pode ser qualquer pessoa e de forma mais exata, é quem remove o órgão ou tecido visando o lucro. O sujeito passivo do delito aqui apresentado seria a pessoa que tem seus órgãos, tecidos ou partes do corpo retirados em desacordo com a lei. Existindo ainda a modalidade tentada do delito e configurando crime de ação penal pública incondicionada.

Ressalta-se que a Lei 9.434/97 divide-se em seis capítulos, trazendo disposições gerais, disposições no caso das modalidades inter vivos e post mortem, disposições complementares, as sanções penais e administrativas e as disposições finais.

De modo geral, a lei determina o que entra ou não no rol de possibilidades para disposição gratuita, onde pode ser realizado o transplante, quem é a pessoa capacitada para fazer, os requisitos no caso de o doador estar com vida, os requisitos para alegação de morte encefálica, as vedações quanto a estas modalidades, as sanções penais impostas para cada delito cometido, as sanções administrativas, e as atenuantes a depender de cada caso (BRASIL, 1997).

Além da penalização para as pessoas que compram e vendem os órgãos, aquele que de alguma forma facilita, intermedeia, aufere ou promove qualquer vantagem com a transação será penalizado da mesma forma que os traficantes, como prevê o parágrafo único do artigo 15. Entretanto, caso a pessoa que doou e a pessoa que recebeu não souberem que o médico, por exemplo estava lucrando, estas não irão incorrer na pena prevista em lei.

Ressalte-se que caso os médicos ou outras pessoas que realizem o transplante souberem que os órgãos foram obtidos de forma ilegal, serão eles responsabilizados com base no artigo 16. Irão ser penalizados também tanto aqueles que transportarem quanto os que fizerem anúncios sabendo do intuito de lucro (BRASIL, 1997).

A verdade é que embora existam vários tipos penais que podem ser relacionados como tráfico de órgãos, apenas o artigo 15 da Lei $\mathrm{n}^{\circ}$ 9.434/97 versa de maneira específica sobre o comércio e venda de tecidos, órgãos ou partes do corpo humano, em que será cominada uma pena privativa de reclusão de 3 a 8 anos, cumulada com a pena de multa de 200 a 360 dias-multa, sendo 
que a fixação de tal pena efetivamente não impede a prática do crime de tráfico de órgãos, obtendo apenas uma eficácia simbólica, posto que a norma apenas possui uma vocação de eficácia, mas tal vocação efetivamente não supõe que a lei seja eficaz no plano real (BOTERO BERNAL, 2010, p. 21). Portanto, no Brasil, igualmente aos outros países mencionados neste trabalho, o tráfico ou comercialização de órgãos é uma realidade, porém a lei que criminaliza tais condutas não consegue impedir que elas sejam praticadas, podendo-se até mesmo afirmar que para aquele que necessita e pode pagar por um órgão com a finalidade de salvar a sua vida ou de alguém próximo, a infrigência da lei é o menor dos problemas.

\section{CONSIDERAÇÕES FINAIS}

Após fazer uma análise da linha temporal desde a evolução do modo de pensar do ser humano sobre a quebra de paradigmas, onde houve o início dos estudos do corpo humano até o desenvolvimento no que diz respeito às leis que regulam o transplante de órgãos e a realidade quanto ao tráfico, é possível observar alguns pormenores.

Com base na análise legislativa é visível que a lei brasileira, ainda que não tenha sofrido alterações nos últimos anos, posto que a sua última alteração fora realizada no ano de 2001, ainda consiste num instrumento normativo plausível para tratar sobre o tema referente ao transplante de órgãos, bem como para incriminar condutas que visem a realizar tal transplante de forma ilegal.

Contudo, a realidade intrigante é o fato de que mesmo com a demora relacionada ao Sistema Único de Saúde, e o Brasil tendo aumentado as taxas de transplantes ao longo do tempo, chegando a ocupar o segundo lugar no ranking mundial de transplante de órgãos, sendo realizado no país até o mês de junho de 2019, o total de 13.263 transplantes (BRASIL, 2019), esse número não é suficiente para sanar a necessidade no que diz respeito aos receptores. E por esse motivo é que surge o crime de tráfico ou comercialização ilegal de órgãos.

Apesar de ser algo real, é um delito velado pelo fato de ser pouco discutido e, igualmente, não há estatísticas oficiais que divulguem acerca da quantidade desses crimes que foram praticados no país e se houve condenação dos envolvidos. Tal situação pode gerar na mente das pessoas involucradas com o crime a sensação de impunidade, tendo em vista que o Estado não dá uma resposta penal àqueles que vieram a praticar o crime. Diante desses, o que se pode fazer é supor alternativas que possam um dia se tornar modificadoras positivas deste cenário. Inicialmente, é preciso conscientizar a população acerca da possibilidade de doação de órgãos após a morte,

Ciências Sociais Aplicadas em Revista, v. 20, n. 38, p. 261-277, semestral, janeiro-junho, 2020. 
bem como a conscientização dos familiares, tendo em vista que, em caso de morte sem que haja anteriormente o consentimento do possível doador, são aqueles que podem permitir que o transplante seja realizado. Assim, através da criação de Políticas Públicas, com o objetivo de conscientização das famílias para que elas não se tornem fator impeditivo ao transplante é de suma importância, posto que a doação não lhes trará nenhum prejuízo, ao contrário, pode contribuir no salvamento da vida de outras pessoas.

\section{REFERÊNCIAS}

AMARAL, Débora Maria Gomes Messias. Tráfico de órgãos: um crime invisível. 08 de set. 2018. Disponível em: <https://jus.com.br/artigos/68814/trafico-de-orgaos-um-crimeinvisivel/2>. Acesso em: 15 de outubro de 2019.

ASSOCIAÇÃO BRASILEIRA DE TRANSPLANTE DE ÓRGÃOS. Registro brasileiro de transplantes. Disponível em: http://www.abto.org.br/abtov03/Upload/file/RBT/2019/rbt20191sem- leitura.pdf. Acesso em: 17 de setembro de 2019.

BATTAGLINI, Giulio. Direito Penal. Parte Geral. São Paulo: Editora da Universidade de São Paulo, 1973. Disponível em: https://www.estantevirtual.com.br/livros/giulio-battaglini/direitopenal-parte-geral/1556674562. Acesso em: 15 de out. 2019.

BOTERO BERNAL, Andrés. Ensayos jurídicos sobre Teoría del Derecho. Buenos Aires: La Ley, 2010.

BRASIL. Associação Brasileira de Transplante de Órgãos. Disponível em: http://www.abto.org.br/abtov03/upload/file/rbt/2013-parcial(1).pdf. Acesso em: 07 outubro de 2019.

. Constituição da República Federativa do Brasil de 05 de outubro de 1988.

Disponível em: http://www.planalto.gov.br/civil_03/constituicao/constituicao.htm. Acesso em: 10 de setembro de 2019.

Lein ${ }^{\circ}$ 4.280, de 6 de novembro de 1963. Disponível em: http://www.planalto.gov.br/ccivil_03/leis/1950-1969/L4280.htm. Acesso em: 10 de seembro de 2019.

Lei $n^{o}$ 5.479, de 10 de agosto de 1968. Disponível em: http://www.planalto.gov.br/ccivil_03/leis/1950-1969/L5479.htm. Acesso em: 11 de setembro de 2019.

, Lei $n^{o} 8.489$, de 18 de novembro de 1992. Disponível em:

http://www.dji.com.br/leisordinarias/1997-009434-lt/8489-92.htm. Acesso em: 11 de setembro de 2019.

Ciências Sociais Aplicadas em Revista, v. 20, n. 38, p. 261-277, semestral, janeiro-junho, 2020. 
. Lei $n^{o}$ 9.434, de 4 de fevereiro de 1997. Disponível em:

<https://www.jusbrasil.com.br/topicos/11452772/artigo-14-da-lei-n-9434-de-04-de-fevereirode-1997>. Acesso em: 11 de setembro de 2019.

. Ministério da Saúde. Agência Nacional de Vigilância Sanitária. Resolução RDC $n^{o}$ 66 de 21 de dezembro de 2009. Dispõe sobre o transporte no território nacional de órgãos humanos em hipotermia para fins de transplantes. Disponível em: http://bvsms.saude.gov.br/bvs/saudelegis/anvisa/2009/rdc0066_21_12_2009.html 15 de setembro de 2019.

Ministério da Saúde. Brasil registra aumenta no número de transplantes mais difíceis de serem realizado. 27 de setembro de 2019. Disponível em:

https://www.saude.gov.br/noticias/agencia-saude/45850-brasil-registra-aumento-no-numero-detransplantes-mais-dificeis-de-serem-realizados Acesso em: 20 de abril de 2020.

BUONICORE, Giovana Palmieri. Tráfico de órgãos humanos: análise à luz do ordenamento jurídico-penal e da (bio) ética. 2013. 33 f. Tese (Doutorado) - Curso de Direito, Faculdade de Direito da Pontifícia Universidade Católica do Rio Grande do Sul, Rio Grande do Sul, 2013. Disponível em: <http://tede2.pucrs.br/tede2/bitstream/tede/4934/1/452362.pdf>. Acesso em 08 abri. 2019.

CASABONA, Carlos Maria Romeo. El Medico y El Derecho Penal: I- La atividade curativa (licitude y responsabilidade penal). Barcelona: Boch, 1979.

CONSELHO FEDERAL DE MEDICINA. Portaria $n^{\circ} 01$ de 2012. Disponível em: http://www.portalmedico.org.br/resolucoes/CFM/1997/1480_1997.htm. Acesso em: 17 de novembro de 2019.

Resolução $n^{\circ}$ 1480/97. Disponível em:

http://www.portalmedico.org.br/resolucoes/CFM/1997/1480_1997.htm. Acesso em: 17 de nov. 2019.

DANIEL, Marcos. Doação de Órgãos: transplantes, lista de espera e como ser doador. 2018. Disponível em: <http://portalms.saude.gov.br/saude-de-a-z/doacao-de- orgaos>. Acesso em: 12 de março de 2020.

FERNÁNDEZ, Javier Gafo. 10 Palavras-chave em Bioética. Porto Alegre: Paulinas, 2000.

GARCIA, Valter Duro et al. Transplantes de órgãos e tecidos. Em: História dos transplantes. V. D. Garcia, M. Abbud-Filho, E. Keitel, J. Neumman, JMO Pestana. São Paulo: Segmento Farma, 2006.

IANDOLI, Rafael. O que impede o Brasil de melhorar ainda mais seu índice de doação de órgãos. Disponível em: <https://www.nexojornal.com.br/expresso/2017/10/30/O-queimpede-o-Brasil-de-melhorar-ainda-mais-seu-\%C3\%ADndice-de-doa\%C3\%A7\%C3\%A3o- de\%C3\%B3rg\%C3\%A3os>. Acesso em: 09 de janeiro de 2020.

JUNGES, José Roque. Bioética. Perspectivas e desafios. São Leopoldo: Editora Unisinos, 1999. 
LIMA, Madalena. Transplantes. Relevância Jurídico-penal (Legislação actual). Portugal: Almedina, 1996.

LEITE, Rita de Cássia Curvo. Transplante de órgãos e Tecidos e os Direitos da Personalidade. São Paulo: Juarez de Oliveira, 2000.

PELLEGRINI, Luis. Tráfico de órgãos humanos: Um mercado negro em expansão. 2018. Disponível em: https://www.brasil247.com/oasis/trafico-de-orgaos-humanos-um- mercadonegro-em-expansao. Acesso em: 10 de janeiro de 2020.

PAVESI, Paulo. Tráfico de órgãos humanos no Brasil: O que a máfia não quer que você saiba. 2013. Disponível em: https://books.google.com.br/books?id=s3arCAAAQBAJ\&pg=PA193\&lpg=PA193\&dq=falsif ica\%C3\%A7\%C3\%A3o+de+documentos+de+morte+encefalica\&source=bl\&ots=V6Cw77Dt UH\&sig=ACfU3U3jlyxesfkOdkcWlQDfOftEa7kGXg\&hl=ptBR\&sa=X\&ved=2ahUKEwihys mH9tPlAhUpILkGHft_DI8Q6AEwF3oECAkQAQ\#v=onepage\&q=falsifica\%C3\%A7\%C3\%A3 o\%20de\%20documentos\%20de\%20morte\%20encefalica\&f=false. Acesso em: 17 de nov. 2019.

SILVA, Hugo. Tráfico de órgãos no Brasil: uma análise da Lei $9.434 / 97$ a partir do princípio da dignidade da pessoa humana. 2016. Disponível em: <https://hugoleandrosilva.jusbrasil.com.br/artigos/332387333/trafico-de-orgaos-no-brasiluma-analise-da-lei-9434-97-a-partir-do-principio-da-dignidade-da-pessoa-humana>. Acesso em: 09 abr. 2016.

SOCIEDADE BRASILEIRA DE NEFROLOGIA. Cinquenta e cinco anos do primeiro transplante no Brasil. São Paulo, 10 de abr. de 2019. Disponível em: < https://sbn.org.br/blog/cinquenta-e-cinco-anos-do-primeiro-transplante-no-brasil/> . Acesso em: 15 de out. 2019.

UNIVERSIDADE DO ESTADO DE SÃO PAULO (USP). Transplantes no Brasil, uma história de 50 anos. Em: Jornal da USP, São Paulo, 08 de fevereiro. de 2018. Disponível em: $<$ https://jornal.usp.br/atualidades/transplantes-no-brasil-uma- historia-de-50-anos/>. Acesso em: 15 de dezembro de 2019.

WORLD HEALTH ORGANIZATION. Global Classrooms: "Medical Tourism And The Illicit Trafficking Of Human Organs”, 2009, University Model United Nations Conference. Disponível em: http://livrozilla.com/doc/282561/daniela-alves-pereira-de-andrade-otr\%C3\%A1fico-de. Acesso em: 15 de outubro de 2019.

China deixará de extrair órgãos de presos executados para transplante. 05 de dezembro de 2014. Disponível em: https://brasil.elpais.com/brasil/2014/12/04/internacional/1417726650_150714.html.Acesso em: 16 de out. 2019.

Pobreza estimula comércio ilegal de órgãos no Paquistão. 27 de junho de 2017. Disponível em: https://oglobo.globo.com/sociedade/saude/pobreza-estimula-comercio-ilegal-de-orgaos-nopaquistao-21524709. Acesso em: 10 de novembro de 2019. 
Significado de Deep Web. 18 de março de 2019. Disponível em:

https://www.significados.com.br/deep-web/. Acesso em: 15 de outubro 2019. 